\title{
The association between hypozincemia and aortic stenosis prevalence in hemodialysis patients: a single-center cross-sectional study
}

Satoshi Matsui ${ }^{1 *}$ (D) Tomonaga Ameku', Daisuke Takada² and Shinji Ono ${ }^{1}$

\begin{abstract}
Background: Hypozincemia contributes to phosphate-induced vascular calcification in model animals of renal failure, but the association between hypozincemia and aortic stenosis (AS) prevalence in patients with end-stage kidney disease remains unreported in clinical settings.

Methods: To investigate the association between hypozincemia and AS prevalence in patients undergoing hemodialysis, we designed a single-center cross-sectional study. Our outcome "AS" was defined as prevalence of moderate or severe AS or surgical history for AS. Depending on serum zinc levels, we divided patients undergoing hemodialysis into deciles. The association between hypozincemia and AS prevalence was analyzed via logistic regression adjusted for age, sex, dialysis vintage, diabetes history, serum albumin, and history of taking calciumcontaining phosphate binder.

Results: Ninety-three patients undergoing hemodialysis were eligible. The mean serum zinc level was $61.3 \pm$ $13.9 \mathrm{\mu g} / \mathrm{dL}$. Twelve patients who belonged to 1 st decile had serum zinc levels $\leq 48 \mu \mathrm{g} / \mathrm{dL}$. Of these twelve patients, six patients (50\%) had AS. On the other hand, of eighty one patients who belonged to 2 nd-10th deciles (serum zinc levels $>48 \mu \mathrm{g} / \mathrm{dL}$ ), thirteen patients $(16 \%$ ) had AS. Hypozincemia (serum zinc levels $\leq 48 \mu \mathrm{g} / \mathrm{dL}$ ) was associated with AS prevalence ( $P=0.038$; odds ratio 4.43; $95 \%$ confidence interval 1.09-18.0).

Conclusions: AS was more prevalent in patients undergoing hemodialysis with severe hypozincemia in our crosssectional study, although interventional studies are required to elucidate the benefit of zinc supplementation for AS progression.
\end{abstract}

Keywords: Aortic stenosis, Cross-sectional study, Patients undergoing hemodialysis, Hypozincemia, Vascular calcification

\footnotetext{
* Correspondence: satoshimatsui540923@yahoo.co.jp

${ }^{1}$ Departments of Nephrology and Hypertension, Mitsubishi Kyoto Hospital, 1

Katsuragosho-chou, Nishikyo-ku, Kyoto 615-8087, Japan
}

Full list of author information is available at the end of the article

(c) The Author(s). 2020 Open Access This article is licensed under a Creative Commons Attribution 4.0 International License, which permits use, sharing, adaptation, distribution and reproduction in any medium or format, as long as you give appropriate credit to the original author(s) and the source, provide a link to the Creative Commons licence, and indicate if changes were made. The images or other third party material in this article are included in the article's Creative Commons licence, unless indicated otherwise in a credit line to the material. If material is not included in the article's Creative Commons licence and your intended use is not permitted by statutory regulation or exceeds the permitted use, you will need to obtain permission directly from the copyright holder. To view a copy of this licence, visit http://creativecommons.org/licenses/by/4.0/ The Creative Commons Public Domain Dedication waiver (http://creativecommons.org/publicdomain/zero/1.0/) applies to the data made available in this article, unless otherwise stated in a credit line to the data. 


\section{Introduction}

Serum zinc $(\mathrm{Zn})$ levels in patients with end-stage kidney disease (ESKD) tend to be low because these patients are often undernourished owing to chronic inflammation, uremia, and food restrictions [1]. Hypozincemia leads to dysgeusia, loss of appetite, delayed wound healing, anemia, and resistance to erythropoiesis-stimulating agents in patients with ESKD [2].

Vascular calcification in patients with ESKD is closely related to rapid progression of ischemic heart disease, peripheral artery disease, and aortic stenosis (AS), which become leading causes of morbidity and mortality. An association between hypozincemia and phosphateinduced vascular calcification was recently reported in model animals of aging and renal failure [3]. Oxidative stress is also associated with vascular calcification in CKD (chronic kidney disease) patients [4]. Increased superoxide dismutase copper $(\mathrm{Cu})$ - $\mathrm{Zn}$, a $\mathrm{Zn}$-containing antioxidant that defends against oxidative stress that can lead to aortic valve degeneration, was reported in aortic valve samples from patients with AS [5]. Although the acceleration of AS progression due to vascular calcification was suggested in patients with ESKD [6-8], an association between hypozincemia and vascular calcification or AS progression in clinical settings has not ever been reported.

We designed a single-center cross-sectional study of patients undergoing hemodialysis to investigate the association between severe hypozincemia and AS prevalence.

\section{Methods}

\section{Patients}

Patients undergoing hemodialysis who had regularly attended hemodialysis sessions three times a week at the hospital during the first week of July 2019 were enrolled. The hospital is a general hospital with 188 hospital beds and 24 medical departments. We excluded patients with a dialysis vintage of less than 2 years or had missing blood samples or Zn supplementation.

\section{Measurement of serum zinc concentrations}

All covariates except for serum ferritin and intact parathyroid hormone (iPTH) were sampled in July 2019. Blood samples were obtained just before the dialysis sessions on Monday or Tuesday of the first week. Measurements of the concentrations, including serum $\mathrm{Zn}$, copper, and iPTH, were processed and analyzed by SRL, Inc. (Tokyo, Japan). Kt/V for urea (K: dialyzer clearance of urea, $\mathrm{t}$ : dialysis time and V: urea distribution volume) was calculated during the first week as per Daugirdas et al. [9]. Serum ferritin and iPTH were measured during the last 3 months of the study. Blood pressure was measured just before the 2nd dialysis session during the first week. Calcium, bicarbonate, and glucose concentrations of dialysate used in the study were $2.5 \mathrm{mEq} / \mathrm{L}, 28 \mathrm{mEq} / \mathrm{L}$, and $100 \mathrm{mg} / \mathrm{dL}$, respectively.

\section{Covariates}

Serum $\mathrm{Zn}$ levels were divided into deciles, and the lowest category (1st decile) was regarded as the "low- $Z n$ group." We used the Stata command "xtile zn_10 = sZn, nquantiles (10)" in order to divide them into deciles. Serum albumin was divided into two groups $(<3.0 \mathrm{~g} / \mathrm{dL}$ or $\geq 3.0 \mathrm{~g} / \mathrm{dL}$ ). Our outcome was prevalence of moderate or severe AS, diagnosed by (1) transthoracic echocardiography results (average pressure gradient $>25 \mathrm{mmHg}$, jet velocity $>3.0 \mathrm{~m} / \mathrm{s}$ or aortic valve area $\leq 1.5 \mathrm{~cm}^{2}$ ) or (2) surgical history of aortic valve replacement for AS. Echocardiography was performed within a year before or after the blood sampling. Five expertized technicians in the single center performed the transthoracic echocardiography, and they were blind to serum zinc levels.

\section{Statistical methods}

Parameters for the low-Zn group (1st decile) and the other groups (2nd-10th deciles) were compared via the Mann-Whitney test (Table 1). To analyze the association between hypozincemia and AS prevalence, logistic regression was performed using 5 models. Model 1 is crude, and model 2 is adjusted for age and sex, and model 3 for age, sex, dialysis vintage, and diabetes history. Model 4 is adjusted for age, sex, dialysis vintage, diabetes history, and serum albumin. Model 5 is adjusted for age, sex, dialysis vintage, diabetes history, serum albumin, and history of taking calcium-containing phosphate binder. Analyses were performed using STATA software, version 14.2 (StataCorp LLC, College Station, TX, USA).

\section{Results}

\section{Baseline characteristics}

Of all 114 patients, 19 with a dialysis vintage less than 2 years, one who had $\mathrm{Zn}$ supplementation, and one who missed the blood sampling session were excluded. Finally, 93 patients undergoing hemodialysis were eligible for analysis (Fig. 1).

The mean serum Zn level was $61.3 \pm 13.9 \mu \mathrm{g} / \mathrm{dL}$. First, we confirmed the linearity between serum $\mathrm{Zn}$ levels and AS prevalence. Twelve patients (13\%) were categorized in the low-Zn group, with serum $\mathrm{Zn}$ levels $\leq 48 \mu \mathrm{g} / \mathrm{dL}$. Of these twelve patients in the low-Zn group, six patients (50\%) had AS. On the other hand, of eighty one patients in the other groups (2nd-10th deciles, serum zinc levels $>48 \mu \mathrm{g} / \mathrm{dL}$ ), thirteen patients (16\%) had AS. A patient $(8.3 \%)$ in the low-Zn group had history of surgery for AS; four patients (4.9\%) in another group had history of surgery for AS. Three patients had surgery within a year before the sampling. A patient had surgery 
Table 1 Baseline characteristics of participants in a single-center cross-sectional study of hypozincemia and aortic stenosis prevalence

\begin{tabular}{|c|c|c|c|}
\hline & $\mathrm{Zn} \leq 48$ (1st decile) & $48<$ Zn (2nd-10th deciles) & $P$ value \\
\hline Number of patients & $12(13 \%)$ & $81(87 \%)$ & \\
\hline AS & $6(50 \%)$ & $13(16 \%)$ & $<0.01$ \\
\hline Surgical history of AS & $1(8.3 \%)$ & $4(4.9 \%)$ & 0.58 \\
\hline Age & $75.3 \pm 12.5$ & $70.6 \pm 9.9$ & 0.034 \\
\hline Male & $9(75 \%)$ & $45(56 \%)$ & 0.21 \\
\hline Height (cm) & $164.9 \pm 8.7$ & $159.8 \pm 8.8$ & 0.1 \\
\hline Dw (kg) & $57.5 \pm 10.9$ & $53.4 \pm 11.3$ & 0.19 \\
\hline Diabetes & $3(25 \%)$ & $22(27 \%)$ & 0.88 \\
\hline Dialysis vintage (year) & $11.3 \pm 8.7$ & $10.9 \pm 7.3$ & 0.94 \\
\hline $\mathrm{Zn}(\mu \mathrm{g} / \mathrm{dL})$ & $45.0 \pm 4.3$ & $63.7 \pm 13.1$ & $<0.01$ \\
\hline ALB $(g / d L)$ & $3.2 \pm 0.4$ & $3.5 \pm 0.3$ & 0.043 \\
\hline $\mathrm{Hb}(\mathrm{g} / \mathrm{dL})$ & $11.1 \pm 1.4$ & $11.4 \pm 1.0$ & 0.1 \\
\hline Ferritin (ng/mL) & $135.6 \pm 45.1$ & $119.0 \pm 91.2$ & 0.12 \\
\hline Cre (mg/dL) & $9.4 \pm 1.7$ & $10.5 \pm 2.4$ & 0.09 \\
\hline $\mathrm{Ca}(\mathrm{mg} / \mathrm{dL})$ & $9.3 \pm 0.4$ & $9.3 \pm 0.6$ & 0.72 \\
\hline$P(\mathrm{mg} / \mathrm{dL})$ & $5.0 \pm 0.8$ & $5.1 \pm 1.6$ & 0.86 \\
\hline $\mathrm{Ca} \times \mathrm{P}$ & $46 \pm 7.5$ & $47.5 \pm 14$ & 0.95 \\
\hline$P$ ave & $5.2 \pm 0.8$ & $5.2 \pm 1.0$ & 0.83 \\
\hline $\mathrm{K}(\mathrm{mEq} / \mathrm{L})$ & $5.0 \pm 0.6$ & $5.0 \pm 0.7$ & 0.87 \\
\hline $\mathrm{Mg}(\mathrm{mg} / \mathrm{dL})$ & $2.5 \pm 0.2$ & $2.8 \pm 0.4$ & $<0.01$ \\
\hline $\mathrm{Cu}(\mu \mathrm{g} / \mathrm{dL})$ & $90 \pm 23$ & $87.1 \pm 19.1$ & 0.68 \\
\hline iPTH (pg/mL) & $184.0 \pm 112.1$ & $133.7 \pm 105.3$ & 0.11 \\
\hline LDL-chol (mg/dL) & $75.9 \pm 18.9$ & $82.9 \pm 25.3$ & 0.29 \\
\hline TAC-BUN & $48.2 \pm 6.6$ & $48.5 \pm 9.6$ & 1 \\
\hline Kt/N for urea & $1.44 \pm 0.18$ & $1.54 \pm 0.19$ & 0.17 \\
\hline $\mathrm{SBP}(\mathrm{mmHg})$ & $137.7 \pm 19.0$ & $142.8 \pm 16.7$ & 0.43 \\
\hline \multicolumn{4}{|l|}{ Drug } \\
\hline Vitamin D & $10(83 \%)$ & $76(92 \%)$ & 0.12 \\
\hline Calcium-containing phosphate binder & $8(67 \%)$ & $51(61 \%)$ & 0.51 \\
\hline $\mathrm{ACE} / \mathrm{ARB}$ & $9(75 \%)$ & $48(58 \%)$ & 0.34 \\
\hline Calcimimetics & $7(58 \%)$ & $41(49 \%)$ & 0.71 \\
\hline P absorbents ${ }^{\mathrm{a}}$ & $1.5 \pm 0.8$ & $2.1 \pm 0.9$ & 0.024 \\
\hline Warfarin & $5(42 \%)$ & $16(19 \%)$ & 0.1 \\
\hline Statins & $5(41.7 \%)$ & $24(29.6 \%)$ & 0.4 \\
\hline \multicolumn{4}{|l|}{ Past history } \\
\hline $\mathrm{IHD}$ & $5(41.7 \%)$ & 22 (27.2 \%) & 0.3 \\
\hline CVD & $2(16.6 \%)$ & $14(17.3 \%)$ & 0.96 \\
\hline ASO & 4 (33.3 \%) & 16 (19.8\%) & 0.29 \\
\hline
\end{tabular}

Data are $n$ (\%) and mean (SD). AS aortic stenosis, Dw dry weight, Zn serum zinc, ALB serum albumin, Hb serum hemoglobin level, Cre serum creatinine, Ca serum calcium corrected by serum albumin, $P$ serum phosphate, $C a \times P$ product of $C a$ and $P, P$ ave average value of serum phosphate during this study, $K$ serum potassium, $M g$ serum magnesium, $C u$ serum cupper, iPTH serum intact parathyroid hormone, $L D L$-chol serum low-density lipoprotein cholesterol, TAC-BUN timeaveraged concentration of blood urea nitrogen, SBP systolic blood pressure, $A C E / A R B$ angiotensin-converting enzyme inhibitor/angiotensin II receptor blocker, $P$ absorbents phosphorus adsorbents, IHD ischemic heart disease, CVD cerebrovascular disease, ASO arteriosclerosis obliterans ${ }^{a}$ Number of different $\mathrm{P}$ absorbents taken by patients 


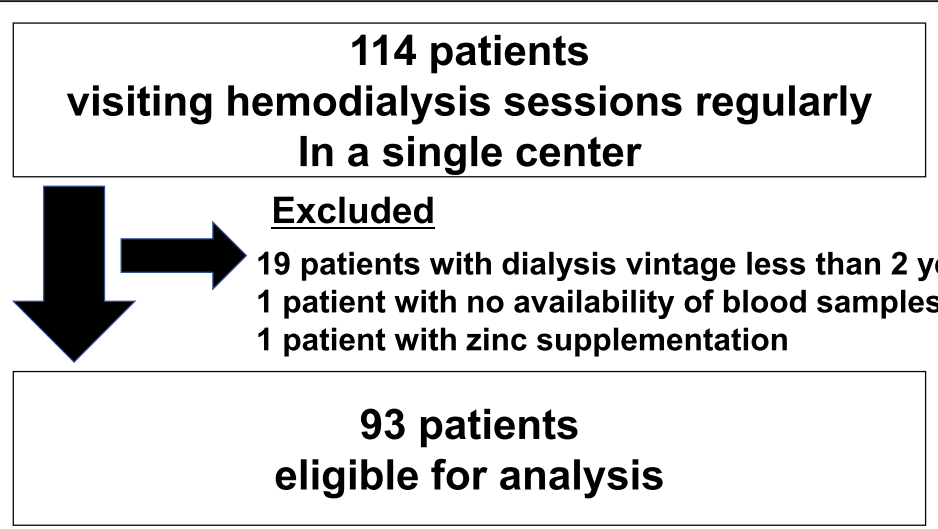

Fig. 1 Flowchart for this single-center cross-sectional study

within 2 years before the sampling. A patient had surgery 4 years before the sampling. Patients in the low- $\mathrm{Zn}$ group were significantly older than those in the other groups $(\mathrm{Zn}>48 \mu \mathrm{g} / \mathrm{dL}$; age $75.3 \pm 12.5$ years old versus $70.6 \pm 9.9$ years old, $P=0.034$ ). The serum albumin and magnesium levels in the low-Zn group were lower than those in the other groups $(3.2 \pm 0.4 \mathrm{~g} / \mathrm{dL}$ versus $3.5 \pm$ $0.3 \mathrm{~g} / \mathrm{dL}, P=0.043 ; 2.5 \pm 0.2 \mu \mathrm{g} / \mathrm{dL}$ versus $2.8 \pm 0.4 \mu \mathrm{g} /$ $\mathrm{dL} ; P<0.01$, respectively). Patients in the low-Zn group had taken fewer phosphorus adsorbent types $(1.5 \pm 0.8$ versus $2.1 \pm 0.9, P=0.024)$. The serum calcium, phosphate, serum calcium-phosphorus products, systolic blood pressure, dialysis vintage, and diabetes history did not significantly differ between the low- $\mathrm{Zn}$ group and the other groups (Table 1).

\section{Hypozincemia and AS}

Severe hypozincemia (low-Zn group, $\mathrm{Zn} \leq 48 \mu \mathrm{g} / \mathrm{dL}$ ) was associated with AS prevalence $(P=0.038$; odds ratio 4.43 ; $95 \%$ confidence interval $1.09-18.0)$ via logistic regression, adjusted for age, sex, dialysis vintage, diabetes history, serum albumin, and history of taking calciumcontaining phosphate binder in model 5 (Table 2).

Table 2 Associations between serum zinc level and covariates with aortic stenosis prevalence

\begin{tabular}{llll}
\hline Model & OR & $\mathbf{9 5 \% ~ C l}$ & $\boldsymbol{P}$ value \\
\hline Model 1 & 5.23 & $1.46-18.8$ & 0.011 \\
Model 2 & 4.38 & $1.16-16.5$ & 0.029 \\
Model 3 & 4.51 & $1.15-17.6$ & 0.03 \\
Model 4 & 4.55 & $1.15-18.0$ & 0.031 \\
Model 5 & 4.43 & $1.09-18.0$ & 0.038
\end{tabular}

$O R$ odds ratio, $\mathrm{Cl}$ confidence interval

Model 1: Crude

Model 2: Adjusted for age + sex

Model 3: Adjusted for model 2 + dialysis vintage (years) + diabetes history

Model 4: Adjusted for model $3+$ serum albumin

Model 5: Adjusted for model $4+$ history of taking calcium-containing phosphate binder
Severe hypozincemia was also associated with AS prevalence in other models (models 1-4).

\section{Discussion}

In our cross-sectional study, the mean serum $\mathrm{Zn}$ level of the patients undergoing hemodialysis was low, and the low-Zn group was significantly associated with AS prevalence in several models.

The mean serum $\mathrm{Zn}$ level was $61.3 \pm 13.9 \mu \mathrm{g} / \mathrm{dL}$, which is below the normal range of $80-130 \mu \mathrm{g} / \mathrm{dL}$ as defined by the Japanese Society of Clinical Nutrition [10]. Serum $\mathrm{Zn}$ levels tend to be low in patients undergoing hemodialysis because these patients are often undernourished owing to chronic inflammation, uremia, and food restrictions. Shimizu et al. reported that the mean serum $\mathrm{Zn}$ level in Japanese patients undergoing hemodialysis was $61 \pm 10.5 \mu \mathrm{g} / \mathrm{dL}$, and half of all patients had serum Zn levels < $60 \mu \mathrm{g} / \mathrm{dL}$ [11]. In our hospital, $40 \%$ of all patients had serum zinc levels $<60 \mu \mathrm{g} / \mathrm{dL}$ (data not shown). The mean serum Zn level in the study was very similar to that in our study. In our facility, patients in the low- $\mathrm{Zn}$ group had serum $\mathrm{Zn}$ values of $\leq$ $48 \mu \mathrm{g} / \mathrm{dL}$. Most patients undergoing hemodialysis are considered hypozincemic. However, the threshold of hypozincemia to be harmful for patients undergoing dialysis has remained unknown.

Although hypozincemia is common in patients undergoing hemodialysis, aggressive supplementation to normalize serum $\mathrm{Zn}$ levels is controversial. First, various symptoms, such as dysgeusia, loss of appetite, delayed wound healing, anemia, and resistance to erythropoiesisstimulating agents, are often not fully improved even after $\mathrm{Zn}$ supplementation when the serum $\mathrm{Zn}$ levels are normalized. Second, Zn overload poses a risk of Znexcess-induced $\mathrm{Cu}$ deficiency leading to serious complications such as pancytopenia, myelopathy, or subacute associated spinal cord degeneration [12, 13]. 
In addition to these facts, there was no consensus to confirm the usefulness of correcting serum $\mathrm{Zn}$ levels to normal range in all patients undergoing hemodialysis. Correcting serum $\mathrm{Zn}$ levels to normal range might not be necessary in patients undergoing hemodialysis, as in the case of serum phosphate. Thus, we need to rely on a few literatures about patients undergoing hemodialysis. First, Nishime et al. suggest recommended safety ranges (Zn $41.3 \sim 78.3 \mu \mathrm{g} / \mathrm{dL}, \mathrm{Cu} 66.5 \sim 96.5 \mu \mathrm{g} / \mathrm{dL}$ ) in patients undergoing hemodialysis, in terms of causing no deficiency or over shoot in $\mathrm{Zn}$ and $\mathrm{Cu}$ [14]. Second, with reference to a report about oral $\mathrm{Zn}$ supplementation to patients undergoing hemodialysis, the erythropoietin responsiveness index seemed more effectively to be improved in the patients with serum $\mathrm{Zn}$ levels around $48 \mu \mathrm{g} / \mathrm{dL}$ [2]. Serum Zn level $48 \mu \mathrm{g} / \mathrm{dL}$ was similar to the cutoff value of the 1st decile group in this study. The cutoff value in our study did not contradict the past reports, suggesting it would be acceptable in clinical settings.

A recent study found that $\mathrm{Zn}$ supplementation prevented phosphate-induced vascular calcification in vitro and in vivo in animal models of aging and renal failure [3]. That study investigated primary human aortic vascular smooth muscle cells and klotho-hypomorphic $(k l / k l)$, subtotal nephrectomy, and cholecalciferol-overload mouse calcification models. They discovered that zinc sulfate $\left(\mathrm{ZnSO}_{4}\right)$ treatment in cultured vascular smooth muscle cells blunted phosphate-induced calcification, osteo-/chondrogenic signaling, and NF- $\mathrm{BB}$ activation. They identified that $\mathrm{ZnSO}_{4}$ increased the abundance of zinc-finger protein TNF- $\alpha$-induced protein 3 (TNFA IP3), a suppressor of the NF-kB pathway, by zincsensing receptor ZnR/GPR39-dependent upregulation of TNFAIP3 gene expression. In the klotho-hypomorphic $(\mathrm{kl} / \mathrm{kl})$, subtotal nephrectomy, and cholecalciferoloverload mouse calcification models, $\mathrm{ZnSO}_{4}$ supplementation inhibited aortic wall calcification. Their study suggests that $\mathrm{Zn}$ supplementation may prevent or ameliorate vascular calcification in ESKD patients. However, their study used animals with hypozincemia and hyperphosphatemia. In clinical settings, most patients undergoing hemodialysis are hypozincemic but only slightly hyperphosphatemic or even normophosphatemic because they are treated with phosphate-absorbent drugs. Theoretically, $\mathrm{Zn}$ supplementation may have limited effects on patients with normophosphatemia. Mechanisms other than phosphate-induced vascular calcification should be also considered.

Oxidative stress contributes to vascular calcification in CKD patients [4]. One possible mechanism is the antioxidative effect of superoxide dismutase $\mathrm{Cu}-\mathrm{Zn}$, a $\mathrm{Zn}$ containing antioxidant, which must be increased to defend against oxidative stress that can lead to aortic valve degeneration. Martin-Rojas et al. reported that superoxide dismutase $\mathrm{Cu}-\mathrm{Zn}$ was clearly increased in aortic valve samples from 20 patients who underwent aortic valve replacement [5]. Interestingly, some studies showed that $\mathrm{Zn}$ supplementation reduced oxidative stress in patients undergoing hemodialysis $[15,16]$.

The most common cause of death in patients undergoing hemodialysis is cardiovascular events such as heart failure, cerebrovascular events, and myocardial infarction [17]. AS is one of the most important causes of heart failure, sudden death, and severe hypotension during adverse hemodialysis events such as disdialysis syndrome. AS is more prevalent and progresses 2-5 times faster in patients with ESKD than in non-CKD patients because of severe vascular calcification characteristic of patients with ESKD $[18,19]$. Aortic valve calcification in patients with ESKD is reported to accelerate with age, dialysis vintage, diabetes, serum calcium-phosphorus products, hypertension, and calcium supplementation [6-8]. However, whether hypozincemia accelerates aortic calcification and AS progression remains unknown. Our results might suggest that severe hypozincemia could be associated with AS prevalence.

Our study had several limitations. First, because this study was cross-sectional, no causal relationship could be confirmed between hypozincemia and AS incidence. Second, there may have been some unmeasured confounding factors affecting serum $\mathrm{Zn}$ level, AS progression, or vascular calcification. Malnutrition seems to be related with aortic calcification and zinc deficiency among patients undergoing hemodialysis [20, 21]. Although serum albumin was adjusted, we cannot deny such relation may interfere with our analysis. Serum Creactive protein (CRP) is also reported to be another confounding factor [22]. In our facility, we did not measure serum CRP levels routinely in all patients undergoing hemodialysis and could not show them in this study. So, we substitute them for serum ferritin levels which could reflect chronic inflammation status. Third, this study enrolled patients undergoing hemodialysis in a single center. Thus, the number of patients in our study was too small to fully optimize the statistical power in multivariable analyses. Because the small number of patients limited the statistical power, multi-institutional joint research should be considered in the future. Last but not least, the cutoff value of serum $\mathrm{Zn}$ levels "1st vs 2nd to 10th deciles" might be somewhat arbitrary, although it did not contradict the past reports. To make consensus on the serum $\mathrm{Zn}$ level of hypozincemia to be harmful for patients undergoing dialysis, more studies should be needed in the future.

Although our study has several limitations, this is a first cross-sectional report about the association between hypozincemia and AS prevalence in patients undergoing 
hemodialysis and potentially interesting in the absence of effective therapies for resolving vascular arteriosclerosis and calcification in CKD patients.

\section{Conclusion}

AS was more prevalent in patients undergoing hemodialysis with severe hypozincemia in our crosssectional study, although interventional studies are required to elucidate the benefit of zinc supplementation for AS progression.

\section{Abbreviations}

AS: Aortic stenosis; Zn: Zinc; ESKD: End-stage kidney disease; CKD: Chronic kidney disease; Cu: Copper; iPTH: Intact parathyroid hormone; K: Dialyzer clearance of urea; t: Dialysis time; V: Urea distribution volume; kl/kl: Klothohypomorphic; $\mathrm{ZnSO}_{4}$ : Zinc sulfate; TNFAIP3: Zinc-finger protein TNF-ainduced protein 3; CRP: C-reactive protein

\section{Acknowledgements}

We thank Traci Raley, MS, ELS, from Edanz Group (www.edanzediting.com/ac) for editing a draft of this manuscript.

\section{Authors' contributions}

SM designed the study and wrote the paper. SM, TA, and SO performed the research. DT analyzed the data and provided discussion about methods of statistical analysis. The authors read and approved the final version of the manuscript.

\section{Funding}

This study was not supported by any grants or funding.

\section{Availability of data and materials}

The datasets analyzed during the present study are available from the corresponding author on reasonable request.

\section{Ethics approval and consent to participate}

All included patients provided informed consent prior to initiating any studyrelated activities. The study was conducted in accordance with Good Clinical Practice guidelines, applicable regulations, and the ethical principles of the Declaration of Helsinki. The local ethics committees in the hospital approved the study (the committee's reference number is 19-38).

\section{Consent for publication}

All authors agreed on the publication of this study.

\section{Competing interests}

The authors declare that they have no competing interests.

\section{Author details}

'Departments of Nephrology and Hypertension, Mitsubishi Kyoto Hospital, 1 Katsuragosho-chou, Nishikyo-ku, Kyoto 615-8087, Japan. ${ }^{2}$ Department of Healthcare Economics, Kyoto University School of Public Health, Yoshida Konoe-chou, Sakyo-ku, Kyoto 606-8501, Japan.

Received: 22 May 2020 Accepted: 28 October 2020

Published online: 10 November 2020

\section{References}

1. Sato D, Gohda T, Kihara M, Kanaguchi Y, Kobayashi T, Mano S, et al. Effect of zinc acetate dihydrate (NobelzinR) treatment on anemia and taste disorders in patients with chronic kidney disease with hypozincemia. Acta Med Okayama. 2018;72(5):535-8.

2. Kobayashi H, Abe M, Okada K, Tei R, Maruyama N, Kikuchi F, et al. Oral zinc supplementation reduces the erythropoietin responsiveness index in patients on hemodialysis. Nutrients. 2015;7(5):3783-95.

3. Voelkl J, Tuffaha R, Luong TTD, Zickler D, Masyout J, Feger M, et al. Zinc inhibits phosphate-induced vascular calcification through TNFAIP3-mediated suppression of NF-KB. J Am Soc Nephrol. 2018;29(6):1636-48.
4. Huang $M$, Zheng $L, X u H$, Tang $D$, Lin $L$, Zhang J, et al. Oxidative stress contributes to vascular calcification in patients with chronic kidney disease. J Mol Cell Cardiol. 2020;138:256-68.

5. Martin-Rojas T, Gil-Dones F, Lopez-Almodovar LF, Padial LR, Vivanco F, Barderas MG. Proteomic profile of human aortic stenosis: insights into the degenerative process. J Proteome Res. 2012;11(3):1537-50.

6. London GM, Pannier B, Marchais SJ, Guerin AP. Calcification of the aortic valve in the dialyzed patient. J Am Soc Nephrol. 2000;11(4):778-83.

7. Barreto DV, Barreto FC, Carvalho AB, Cuppari L, Cendoroglo M, Draibe SA, et al. Coronary calcification in hemodialysis patients: the contribution of traditional and uremia-related risk factors. Kidney Int. 2005:67(4):1576-82.

8. Adragao T, Pires A, Lucas C, Birne R, Magalhaes L, Gonçalves M, et al. A simple vascular calcification score predicts cardiovascular risk in haemodialysis patients. Nephrol Dial Transplant. 2004;19(6):1480-8.

9. Daugirdas JT. Eliminating the need for routine monthly postdialysis serum urea nitrogen measurement: a method for monitoring $\mathrm{Kt} / \mathrm{N}$ and normalized protein catabolic rate using conductivity determined dialyzer clearance. Semin Dial. 2018;6:633-6.

10. The Japanese Society of Clinical Nutrition. Available online: http://www.jscn. gr.jp/pdf/aen20190423.pdf (Accessed on 11 Jan 2020).

11. Shimizu S, Tei R, Okamura M, Takao N, Nakamura Y, Oguma H, et al. Prevalence of zinc deficiency in Japanese patients on peritoneal dialysis: comparative study in patients on hemodialysis. Nutrients. 2020;12(3):764.

12. Imataki O, Ohnishi H, Kitanaka A, Kubota Y, Ishida T, Tanaka T. Pancytopenia complicated with peripheral neuropathy due to copper deficiency: clinical diagnostic review. Intern Med. 2008;47(23):2063-5.

13. Jaiser SR, Winston GP. Copper deficiency myelopathy. J Neurol. 2010;257(6): 869-81.

14. Nishime K, Kondo M, Saito K, Miyawaki H, Nakagawa T. Zinc burden evokes copper deficiency in the hypoalbuminemic hemodialysis patients. Nutrients. 2020;12(2):577.

15. Mazani M, Argani H, Rashtchizadeh N, Ghorbanihaghjo A, Hamdi A, Estiar MA, et al. Effects of zinc supplementation on antioxidant status and lipid peroxidation in hemodialysis patients. J Ren Nutr. 2013;23(3):180-4.

16. Guo CH, Wang $\mathrm{CL}$. Effects of zinc supplementation on plasma copper/zinc ratios, oxidative stress, and immunological status in hemodialysis patients. Int J Med Sci. 2013:10(1):79-89.

17. Nitta K, Masakane I, Hanafusa N, Taniguchi M, Hasegawa T, et al. Annual dialysis data report 2017, JSDT renal data registry. Renal Replace Ther. 2019; 5:53.

18. Bonow RO, Carabello BA, Chatterjee K, de Leon AC Jr, Faxon DP, Freed MD, et al. American College of Cardiology/American Heart Association Task Force on Practice Guidelines: 2008 focused update incorporated into the ACC/AHA 2006 guidelines for the management of patients with valvular heart disease: a report of the American College of Cardiology/American Heart Association Task Force on Practice Guidelines (Writing Committee to revise the 1998 guidelines for the management of patients with valvular heart disease). Endorsed by the Society of Cardiovascular Anesthesiologists, Society for Cardiovascular Angiography and Interventions, and Society of Thoracic Surgeons. J Am Coll Cardiol. 2008:52:e1-e142.

19. Ureña P, Malergue MC, Goldfarb B, Prieur P, Guédon-Rapoud C, Pétroveret $M$. Evolutive aortic stenosis in hemodialysis patients: analysis of risk factors. Nephrologie. 1999;20(4):217-25

20. Okamoto T, Hatakeyama S, Kodama H, Horiguchi H, Kubota Y, Kido K, et al. The relationship between poor nutritional status and progression of aortic calcification in patients on maintenance hemodialysis. BMC Nephrol. 2018 19(1):71.

21. Choi SR, Lee YK, Cho AJ, Park HC, Han CH, Choi MJ, et al. Malnutrition, inflammation, progression of vascular calcification and survival: Interrelationships in hemodialysis patients. PLoS One. 2019;14(5):e216415.

22. Ishimura E, Okuno S, Kitatani K, Maekawa K, Izumotani T, Yamakawa T, et al. C-reactive protein is a significant predictor of vascular calcification of both aorta and hand arteries. Semin Nephrol. 2004:24:408-12.

\section{Publisher's Note}

Springer Nature remains neutral with regard to jurisdictional claims in published maps and institutional affiliations. 